\title{
Televisão e estesia: considerações a partir das transmissões diretas da Copa do Mundo
}




\section{Resumo}

Fundamentado na semiótica discursiva, este artigo se propõe a descrever a produção de um sentido de natureza mais sensível nas grandes coberturas "ao vivo" da TV, a partir da análise da transmissão dos jogos de futebol da Copa do Mundo 2002. O objetivo é mostrar que este tipo de transmissão instaura um sentido que pode ser descrito nos moldes de um "contágio", tal como este conceito foi proposto pelo semioticista Eric Landowski nos seus trabalhos mais recentes.

\section{Palavras-chave}

semiótica, sentido, televisão, transmissão direta, contágio

\section{Abstract}

With a basis in discursive semiotics, this article proposes to describe the production of a highly sensitive concept within live national television coverage. For purposes of this study, transmissions of football games from the 2002 World Cup were analysed. The objective of the study is to illustrate that this type of live transmission produces a concept that could be initiated within a format know as "contagion", such as the concept proposed by the semioticist Eric Landowski in his most recent studies.

\section{Key words}

semiotic, sense, television, live coverage, contagion 


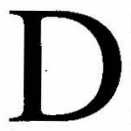

entro dos caminhos abertos pelo De l'Imperfection (1987), este artigo se propõe a descrever na televisão a produção de um tipo de sentido estésico: um sentido de natureza mais sensível que autores, como Eric Landowski, ao desenvolverem as postulações de Algirdas J. Greimas neste seu último livro individual, descreveram depois como um "sentido sentido"- ou, em outros termos, um sentido cuja particularidade é justamente a de ser somática e sensorialmente sentido ${ }^{1}$. Em princípio, pode parecer meio paradoxal, tentar descrever justamente na mídia um sentido da ordem do contato direto, de uma interação corpo a corpo, da co-presença entre os actantes tal como propõe Landowski. Este aparente paradoxo se desfaz se admitirmos a possibilidade de descrever, também na TV, um efeito de "contato" entre sujeitos associado, agora, a um tipo de encontro entre eles numa dimensão espácio-temporal comum construída pelo discurso televisual. Um "contato" que está identificado, nesse caso, à sua inscrição numa mesma duração: uma duração que, ao ser compartilhada por destinadores e destinatários no decorrer de uma transmissão, constitui-se num "lugar" de interação entre esses sujeitos envolvidos no ato comunicativo. Afinal, quando um espectador compartilha com os responsáveis pela emissão e com milhares de outros espectadores de um mesmo tempo, é como se todos estivessem, ao mesmo tempo, num mesmo "lugar" - um lugar que não se constitui mais materialmente, que é um espaço semiótico, um espaço "vivido" e forjado tão somente pela duração da transmissão.

Mais que pelos programas, a construção dessa dimensão espácio-temporal comum a esses sujeitos - o "lugar" que os reúne — depende aqui da transmissão direta da própria programação da

1. Esta proposição foi desenvolvida por Landowski (2001), (1999a), (1996a). 
TV. A despeito de ser composta por programas "ao vivo" e gravados, a programação da TV se faz, se atualiza, no decorrer do tempo crônico e histórico do dia. E é justamente esse efeito de correspondência construído pelo próprio discurso da TV entre o tempo da sua programação e um tempo "do mundo" (crônico e cotidiano) o que está na base desse sentido de "contato" instaurado pela transmissão direta. Com a transmissão da sua programação em tempo real, a TV sincroniza o "passar o tempo" do meu cotidiano com o de grupos sociais mais amplos e, com isso, instaura certas comunidades imaginárias, que surgem a partir dessa experiência comum de "assistir à TV" - comunidades instituídas por um sentido de "estar juntos" forjado pela televisão. Ou seja, "eu vejo o que os outros estão vendo no momento mesmo em que eles estão vendo". O efeito de contato produzido pela transmissão direta parece ser justamente o resultado da sensação de que algo está se atualizando (se fazendo) agora tanto aqui (espaço do "eu") quanto lá (espaço do "outro").

É por saber que a programação está se fazendo no momento mesmo em que ele está assistindo à TV que o. espectador confere à temporalidade construída pelo discurso televisual o mesmo o estatuto da temporalidade cotidiana na qual ele, como outros, está inserido. Por meio das mais diferentes estratégias enunciativas, a TV constrói deliberadamente o tempo da sua programação e dos seus programas diretos como se este fosse o próprio tempo "do mundo". Na frente da tela, o espectador acredita que pode, a qualquer momento, ter "acesso direto" ao que está acontecendo no instante mesmo em que assiste a um determinado programa porque é exatamente isso que a TV broadcasting lhe promete: a maioria das emissoras não hesita em interromper a sua programação ordinária com boletins ou coberturas "ao vivo" quando um fato relevante ocorre nas mais diferentes partes do mundo. Operando em "tempo real", a TV instaura por si um regime de vigilância, uma espécie de "plantão" permanente no "mundo". Quando ligamos a TV, nós nos inserimos, inconsciente e inevitavelmente, nessa duração compartilhada e, através dele, nesse sentido de vigília comum.

Não é por acaso que alguns dos momentos mais marcantes da TV estão associados às grandes coberturas "ao vivo" de fatos históricos, como a chegada do homem à Lua, cobertura da Guerra 
do Golfo, a visita do Papa à Polônia e a Cuba ou o casamento do Príncipe Charles com Lady Diana Spencer. Também não é à toa que, nesse tipo de transmissão direta, revela-se de modo mais evidente a instauração, na TV, desse sentido de natureza estésica: um sentido que depende, antes de mais nada, de um efeito de "contato" proporcionado pelo "ao vivo"; um sentido que está na própria interação entre sujeitos criada pela TV; um sentido que depende de um "sentir" algo junto com o outro num "lugar" forjado pela própria transmissão. É da descrição do tipo de sentido produzido por transmissões dessa natureza que me ocuparei nesse artigo. Para facilitar a análise, me ocuparei, no entanto, de um objeto em particular: a transmissão direta da final da Copa do Mundo 2002, um dos eventos de maior audiência na história recente da televisão ${ }^{2}$. Creio, no entanto, que as postulações feitas aqui podem abrir caminho para a análise de todo um conjunto de coberturas diretas ("ao vivo") e extraordinárias na TV, dotadas, em sua maioria, de um caráter jornalístico.

\section{A cobertura como acontecimento}

Desde a publicação de estudo clássico de Daniel Dayan e Elihu Katz (1996), os objetos semióticos que interessam a este estudo - as emissões que interrompem o fluxo televisual, subvertendo toda a grade de programação rotineira da TV — são identificados entre os teóricos da televisão como news events ou como media events. Dayan e Katz tratam como news events (acontecimentos noticiosos) as grandes coberturas "ao vivo" de um acontecimento inesperado e não-planejado, como $o$ ataque terrorista às torres do World Trade Center (EUA) e, como media events (acontecimentos midiáticos), as grandes coberturas de acontecimentos planejados, as chamadas "cerimônias" televisivas que incluem, entre outras coisas, as solenidades de "Estado", como a posse, renúncia ou morte de governantes; as grandes festas e competições que marcam os calendários nacional ou internacional, como o carnaval, as Olimpíadas ou a

2. Ao longo da sua própria cobertura, a Rede Globo informou que a transmissão da final entre as seleções do Brasil e da Alemanha, em 30 de junho de 2002, teve uma audiência estimada em mais de 2 bilhōes de pessoas em todo mundo. 
Copa do Mundo. Em um ou outro caso, este tipo de acontecimento é associado, por Dayan e Katz, às transmissões diretas monopolistas na maioria dos canais a maior parte do tempo - de determinados momentos históricos, o que confere ao aparelho de TV um outro papel e transforma o próprio ato de assistir à televisão. A discussão aqui proposta, será focada, inicialmente, apenas no que estes autores tratam como grandes "espetáculos culturais" "cerimônias", "celebrações" ou "televisão festiva", embora se saiba, desde já, que muitas das considerações feitas sobre os media events valem também para os news events, dos quais me ocuparei em outro momento.

Tratando deste tipo de transmissão contínua e "ao vivo" como "dias festivos" da televisão, Dayan e Katz definem os "acontecimentos midiáticos" a partir, justamente, da "quebra da rotina da vida das pessoas" provocada por essas emissões extraordinárias das TVs. Com esta interrupção da programação da TV, os "acontecimentos midiáticos" intervêm igualmente no fluxo normal da vida cotidiana das pessoas, propondo-lhes algo também excepcional para fazer e testemunhar. De acordo com os autores, este tipo de transmissão da TV busca, antes de mais anda, instaurar um sentimento coletivo de participação em torno de determinados episódios e/ou personalidades. Concorre para isso o que se pode chamar de uma "preparação midiática" envolvendo os mais variados veículos (TV, jornal, rádio etc.). Anunciando com alarde a sua cobertura "ao vivo" do evento, a própria TV, com a ajuda dos demais media, acaba criando, em torno da sua transmissão, o que Dayan e Katz interpretam como um "clima de feriado" capaz de estimular, entre outras coisas, situações de sociabilidade e solidariedade implicadas diretamente no sentido que este tipo de texto televisual instaura. Segundo os autores, estas transmissões monopolistas não apenas mobilizam grandes audiências, mas também inspiram até uma certa "obrigatoriedade" de acompanhálas pela dimensão que adquirem. Criam, em última instância, as próprias comunidades às quais se dirigem.

No Brasil, não há melhor exemplo dentro desse tratamento extraordinário conferido a uma transmissão, com todas as conseqüências que dele advém, que a transmissão dos jogos de futebol da última Copa do Mundo (2002), em torno dos quais passou a girar 
toda a programação do período. A transmissão dos jogos da seleção brasileira foi ainda mais representativa: nos dias que antecederam a partida o assunto mereceu destaque em todas as mídias e no dia do jogo até o comércio e as repartições públicas fecharam as portas no expediente da transmissão. Muitos torcedores juntaram-se na casa de amigos, de familiares, de vizinhos ou mesmo em bares para assistir à transmissão dos jogos que se transformou, por si, num outro evento. Reunidos em torno da TV, e envolvidos previamente pela sua cobertura, os espectadores não se renderam nem mesmo aos inconvenientes dos horários de transmissão dos jogos da Copa Fifa 2002 ditados pela diferença de fuso horário entre Brasil e Japão/ Coréia $^{3}$. Mesmo nos jogos da seleção brasileira transmitidos durante a madrugada, a Rede Globo de Televisão, detentora dos direitos de transmissão, obteve, durante a Copa, uma audiência média de 5,3 milhões de pessoas só na Grande São Paulo, segundo dados do Ibope ${ }^{4}$. Por todo este seu poder de mobilização, mas principalmente por evidenciar, certos traços definidores do tipo de experiência que se pretende aqui semiotizar, a transmissão da partida final da Copa 2002 entre Brasil e Alemanha será tomada aqui como referência principal, embora não exclusiva, na análise da produção de sentido nos "acontecimentos midiáticos".

Entre os traços que merecem destaque, a nosso ver, está a deliberada construção, durante todo o período da Copa, mas especialmente nos dias de transmissão dos jogos da seleção do Brasil, de um nacionalismo manifesto sobretudo por um "sentimento de pertença" à torcida brasileira: "todos juntos vamos", "tudo é em um só coração", como preconizava, desde os anos 70, uma das célebres músicas que homenageavam, na época, os tricampeões do mundo. $\mathrm{O}$ estímulo a tal sentimento de coletividade, de "corpo", de comunidade, não provinha apenas da narração ufanista dos locutores, repórteres e comentaristas esportivos da Rede Globo. Podia ser observado também nas vinhetas produzidas pela emissora, mostrando manifestações da torcida em todo o Brasil, tanto quanto na publicidade do

3. Sem exceção, todos os jogos da seleção brasileira ou foram exibidos às três horas da madrugada ou, logo cedo, às oito da manhã.

4. Dados divulgados no jornal Folha de São Paulo, 20/06/2002, pág. E10. 
período, enfatizando a vocação, a paixão, a união dos brasileiros através do futebol. Os programas informativos do período - até o sisudo Jornal Nacional - também se encarregaram de construir este "clima de torcida" com entradas contínuas "ao vivo" da concentração da seleção brasileira mesmo quando, claramente, os repórteres não tinham mais nada de novo a informar: sua participação, direto da Coréia ou do Japão, nada mais era que uma nítida estratégia de "aquecimento", de "preparação", do espectador para a transmissão dos jogos. Para os milhõ̃es de brasileiros que só puderam acompanhar a Copa pela TV, a transmissão dos jogos foi, antes mesmo que o próprio jogo, o grande evento vivido.

\section{$\mathrm{O}$ acontecimento como objeto}

$\mathrm{Se}$, no estudo dos "acontecimentos midiáticos", a proposta de Dayan e Katz foi transpor para o processo de comunicação de massas o aparato conceitual do que eles mesmos definem como uma "antropologia dos cerimoniais" , a tentativa aqui será, neste primeiro momento, propor uma abordagem semiótica de tal prática. Para tanto, o desafio inicial parece ser justamente o de entender com que tipo de texto estamos lidando, ou, em outros termos, qual é, nesse caso, o próprio objeto de análise a ser enfrentado. Sem ignorar as formulações pioneiras de Dayan e Katz, parte-se aqui de uma de suas premissas básicas: o objeto a ser estudado é, em qualquer das abordagens teóricas, um acontecimento. Trata-se, no entanto, de um acontecimento que se define, antes de mais nada, por sua natureza midiática: estamos diante de um acontecimento que não se configura como tal se não for motivo de uma transmissão direta e monopolista da TV. É justamente a transmissão direta da TV o que lhe confere uma particularidade em relação a outros fatos de igual relevância histórico-social, mas que, por quaisquer que sejam as razões, não foram televisionados e, por isso mesmo, não foram revestidos da mesma "aura", da mesma repercussão ou, se preferirmos, da mesma "midiaticidade". O objeto a ser analisado não é nem o fato em si,

5. Fundamentada pelos autores em teóricos como E. Durkheim, C. Lévi-Straus e V. Turner, entre outros. 
nem tampouco a transmissão do fato por si só. O objeto de análise é um acontecimento que se produz no momento mesmo em que um determinado fato histórico-social é construído, e vivido, na e pela própria transmissão direta da TV. Nosso objeto possui, portanto, a natureza do que só existe $e m$ ato ${ }^{6}$ : o ato mesmo de sua aparição exhibitio naquele momento no qual se dá a sua produção, veiculação e recepção simultâneas pela TV.

Como já se pode deduzir, o objeto de análise que me interessa aqui não se limita a um conjunto de sintagmas audiovisuais que desfilam na tela da nossa TV (ou àquilo que efetivamente se vê). Nesse caso, o objeto a ser semiotizado é tanto um acontecimento mediado, por definição - quanto uma determinada situação de transmissão. Uma situação que se define por, ao menos, duas condições mutuamente implicadas: a) possui a natureza do espetáculo; b) depende de um tipo de co-presença. $\mathrm{O}$ que configura, inicialmente, esta natureza espetacular? Antes de mais nada, a qualidade do espetacular está associada aqui à performatividade de um certo tipo de representação que se faz no momento mesmo em que se exibe para um espectador qualquer. Por mais tautológica que possa parecer, esta descrição evidencia uma premissa fundamental na configuração do espetacular: não existe espetáculo sem espectador. $\mathrm{O}$ que nos permite concluir, desde já, que o espectador é uma parte constitutiva do próprio espetáculo, mesmo quando no modelo de representação da "cena italiana"7 o papel que lhe caiba seja apenas o de "assistir a". Mas, o que significa exatamente fazer parte de um espetáculo? Mais do que "assistir a algo", a experiência de ser, a rigor, um espectador define-se por "assistir a algo ao mesmo tempo que alguém”. Participar de um espetáculo é, sobretudo, um "ver junto" que se desdobra, muito freqüentemente, em um "viver junto", "sentir junto", enfim, vivenciar uma determinada experiência em comum em torno de uma representação.

6. Utilizo aqui o conceito de em ato nos termos já propostos por E. Landowski (1992), (1996a), (1996b), (1999a); (1999b) e (2000).

7. A expressão "cena italiana" é usada por Jesús G. Requena para designar um modelo fundado na imobilidade do espectador e na ruptura entre o espaço por ele ocupado e os protagonistas da representação (Requena, 1995, pp.68-73). 
Na tentativa de entender como se dá essa experiência, o princípio de organização do dispositivo teatral serve aqui como um modelo de partida ${ }^{8}$. Para conceber, porém, o espetáculo como um tipo de vivência coletiva não é demais retornar às origens históricas dessas experiências ligadas, no mundo ocidental, às matrizes legadas pelo teatro grego. De acordo com Barthes (1986, pp.69-92), o teatro grego era um teatro essencialmente festivo. Como os gregos não adotavam um ou mais dias de descanso semanal, as celebrações religiosas, que envolviam invariavelmente seus grandes espetáculos teatrais, estavam associadas à interrupção do tempo de trabalho e à suspensão da rotina. Na sociedade grega, o espetáculo teatral era oferecido, legal e gratuitamente, a todos os cidadãos e, nestas ocasiões, toda a cidade participava dos grandes festivais cívicos e religiosos que incluíam também proclamações, exposições e procissões, não se limitando apenas a mímesis do espetáculo propriamente dito. Diferente do teatro burguês - modelo da cena italiana - no teatro grego, o espaço cênico aberto e circular (formato de arena) estabelecia uma continuidade entre as posições dos protagonistas do espetáculo e dos espectadores. Sem esta ruptura física, ambos estavam, simbolicamente, no mesmo "lugar" - um lugar no qual se produzia uma autêntica "instalação" do público que, muito à vontade, circulava, comia, brincava, dançava e, o que é mais importante, se confraternizava. Pela descrição de Barthes, uma experiência provavelmente não muito diferente da vivida hoje, por exemplo, por um torcedor quando vai a um estádio assistir a uma final de campeonato de futebol.

$\mathrm{O}$ que nos permite hoje reunir numa mesma descrição as celebrações religiosas gregas, uma final de campeonato paulista no Morumbi, um show de Madonna ou uma transmissão de uma final de Copa do Mundo pela TV? Justamente um tipo de experiência espetacular, nos termos acima propostos, que se traduz tanto pelo sentimento de participação no espetáculo em si — aplaudindo, cantando, gritando, vibrando - , quanto por um "sentimento de pertença" ao grupo de pessoas que em torno dele se reúne ("sou um de-

8. Partimos, aqui, das idéias de E. Landowski (2002), na primeira parte do ensaio "Regimes de presença e formas de popularidade"(7.1. Um espaço cênico). 
les", "faço parte do show"). São estes sentimentos que determinam, aqui, a construção de uma totalidade integral": um "ser junto" alguma coisa por "assistir à algo" juntos. Ser cidadão grego, ser corintiano ou palmeirense, ser fã de Madonna, ser brasileiro. "Ser junto" é muito mais que "sentir" junto com outros, pois o que se configura, aqui, é muito mais que empatia, ou mesmo simpatia. O que se tem, agora, é, antes, um certo sentimento de "comunidade viva" de espectadores que Eric Landowski identifica a uma experiência estésica partilhada: no caso do teatro, mas também em outras formas performáticas de representação, o valor do espetáculo depende, antes de mais nada, de "um modo participativo próximo ao da celebração ritual", de uma espécie de comunhão, dotada de sentido em si mesma, entre aqueles que se reúnem - e se constituem enquanto uma totalidade em torno da ação representada (Landowski, 2002, p.186).

Especificamente no teatro, esta experiência está fundada, segundo Landowski, numa relação intersubjetiva entre corpos-sujeitos, numa proximidade da ordem somática e psicológica (soma e psysis): um tipo de co-presença entre os espectadores que os faz ser uns em relação aos outros ou que os leva a interagir em reciprocidade numa espécie de "contágio", termo usado pelo autor para identificar este sentido estésico produzido por uma interação "carnal" entre sujeitos, ou entre sujeitos e objetos. Nos seus trabalhos mais recentes ${ }^{10}$, a noção de "contágio" (do que passa diretamente de um a outro) se confunde com a própria descrição de um sentido cuja particularidade é justamente ser sentido - um sentido estésico que emerge de determinadas relações de "acesso direto", de "contato imediato", entre sujeito e objeto nas quais o que se tem é, no limite, o própria enunciação com o valor de enunciado. A noção de "contágio" remete, enfim, a distintas formas de vivência nas quais se dá a transmissão de uma certa intelecção, de uma certa emoção ou de uma certa sensação numa relação "corpo a corpo" entre os actantes:

9. A expressão "totalidade integral" é usado por Greimas e Landowski para designar a construção lógica de um tipo de actante coletivo (Greimas \& Landowski, 1981, pp.84-94).

10. Sobre a noção de "contágio" proposta por E. Landowski veja, especialmente, Landowski (2001) e (1999a). 
uma relação que não tem a pretensão de reenviar a nenhuma outra dimensão a não ser a ela mesma; uma relação que deposita em si própria o valor que circula entre os sujeitos. Este tipo de relação manifesta-se, mais freqüentemente, como experiências sensíveis que, dotadas de um fim em si mesmas, instauram sentidos também de natureza somática, como os produzidos por uma perna que tremula nervosa "contagiando" o interlocutor com o nervosismo do outro ou o riso descontrolado de um amigo que "contamina" o outro com sua hilaridade.

\section{O sentido como contágio}

Se esse sentido que se dá na forma um pouco metafórica de um "contágio" pressupõe, nos termos de Landowski, uma co-presença sensível entre os actantes, seria possível identificá-lo também nas relações intersubjetivas instauradas por um meio como a TV? Se admitirmos, inicialmente, que no modo como nos relacionamos com as mídias pode surgir um sentido da ordem do estésico, parece ser possível identificá-lo também a uma das formas de descrição desse "contágio". No caso específico das transmissões diretas, a condição para que se estabeleça esse sentido estésico é igualmente a instauração de um tipo de co-presença entre os actantes. Mas, na televisão, como é que isșo se dá? ${ }^{11}$. A produção desse tipo de sentido depende aqui, como já indiquei antes, do modo como o discurso televisual relaciona a duração da transmissão com uma duração do "mundo" (do fatos) que ela própria constrói narrativamente. O sentido de presença produzido pelo uso do direto emerge justamente do efeito de correspondência entre estas durações: inserindo destinadores e destinatários numa temporalidade que é tanto do "mundo" (e do acontecimento) quanto do discurso (e do aparato midiático), que perpassa tanto as instâncias de produção quanto de recepção, a transmissão do media event faz da sua própria duração uma dimensão na qual se dá um tipo de encontro: todos ao mesmo tempo em torno de uma mesma emissão - e por que não dizer da mesma emoção? - monopolista da TV.

11. Para uma discussão mais aprofundada sobre a construção desse sentido de presença na TV, veja Fechine (2001). 
Paralelamente ao que já definimos antes como sua natureza espetacular, a instauração desse sentido de presença é uma outra condição fundamental para a descrição, numa perspectiva semiótica, das transmissões que Dayan e Katz consideram como acontecimento midiático ${ }^{12}$. Este efeito de presença é também o que está na base de um sentido que se pretende aqui configurar como uma forma de "contágio" através da própria televisão. O tipo de co-presença que se pode descrever nesses "momentos festivos" ou nessas "celebrações rituais" da TV depende justamente da simultaneidade instaurada por uma duração que, por ser compartilhada, coloca os sujeitos em uma mesma dimensão - um tempo e um espaço construídos pela transmissão - , estabelecendo entre eles uma experiência também de reciprocidade. Produz-se assim um efeito de "contato imediato" entre os sujeitos, que, no limite, nada mais é do que uma estratégia de neutralização da oposição entre o "mundo" forjado pela TV e o "mundo" onde os sujeitos históricos e "reais" interagem e se influenciam mutuamente. $\mathrm{Na}$ dimensão espácio-temporal que ela própria estabelece, a transmissão se transforma agora em um "lugar" comum de interação, em uma instância na qual se produz um efeito de "acesso imediato" entre sujeitos que, por não envolver uma experiência somática, não deixa por isso de possuir também uma natureza estésica. Mais que uma prática de interpretação, fundada numa intercâmbio de valores, o que a transmissão de um acontecimento midiático suscita é, antes, a vivência de um tipo de interação definida aqui por uma difusão de afetividades "contagiantes".

De modo mais abrangente, a noção de "contágio" também vem sendo utilizada por Landowski para descrever um regime de interação fundado na "lógica" ou no modelo da união. Para melhor descrever este tipo de relação actancial, Landowski coloca-a no pólo oposto ao regime da junção, no qual está fundada toda a gramática narrativa. Próprio às interações mediadas, que se definem em torno de um intercâmbio de valores, o modelo "juntivo" consiste, basicamente, na descrição teórica de relações de conjunção e disjunção entre actantes. Pode ser tratado, em outros termos, como os próprios per-

12. Relembremos aqui os itens (a) e (b) anteriormente destacados. 
cursos desenvolvidos pelos actantes de um estado a outro (programas narrativos), a partir de estratégias de persuasão e de um fazer fazer entre eles. No modelo da união, ao contrário, o valor semiótico está, segundo Landowski, na relação mesma entre os actantes e nas transformações que neles se operam tão somente por sua co-presença sensível, por uma espécie de "corpo-a corpo estésico" (2001, p.333). Neste caso, a interação "contagiosa": que se opera entre os actantes já não é mais o resultado de um valor qualquer que circula entre eles, levandoos a agir de tal ou qual modo, com este ou aquele propósito. A reciprocidade que se observa agora entre os actantes depende de um fazer ser: da intervenção de um sobre o outro enquanto corpo (soma e physis) e como "corpo", ou seja, como um todo que sente a mesma coisa ao mesmo tempo sem que se saiba (nem haja necessidade de se saber) precisamente o quê, o como, o porquê ou o para quê.

Quando estados corporais ou humores passam, assim, a ser nosso por somente termos sido testemunhas de suas manifestações na aparência do outro, não pode ser por um simples processo de comunicação sígnica. Nem pode ter sido responsável por este nenhuma retórica persuasiva. Muito antes, é por uma espécie de retórica psicossomática de caráter totalizante - "corpo a corpo" mais do que "face a face" - que se impõe sem mediação. Pense-se ainda no bocejar, no espreguiçar, nos espasmos do choro ou, mais especialmente, do riso (Landowski, 1996a, p.39).

É justamente a duas distintas experiências de riso que Landowski recorre para descrever, por contraposição, esses dois regimes de interação que, segundo o autor, servem, antes de mais nada, como referência para a descrição de uma série de estados intermediários.(por gradações) (Landowski, 2001, pp.331-338). Na primeira situação, um sujeito ri de alguma coisa que lhe foi transmitida por alguém. É um riso "calculado" ou motivado produzido pela comicidade de um discurso produzido com este fim. Pensemos, por exemplo, numa circunstância em que um amigo conta uma piada a outro ou num cômico 
que entretém sua platéia, ambos com o propósito deliberado de fazer rir. Na segunda situação, o riso não tem razão, não tem motivo, nem foi o resultado da intenção de um sujeito de fazer um outro rir. O riso surge, aqui, numa espécie de corrente, um sujeito ri apenas porque um outro também ri e, num instante, estão todos rindo sem saber do que ou de quem, como se estivessem séndo "contaminados" pelo riso do outro. O riso pelo riso, riso sem motivação (sem qualquer dimensão cognitiva ou apelo interpretativo), o riso incontrolável, o riso "contagiante": o riso deflagrado apenas pela presença de uns aos outros enquanto "corpos que riem", simplesmente por serem corpos e por estarem juntos; o riso que os faz ser um todo que ri tão somente enquanto dura o riso; o riso que tanto requer quanto resulta em um tipo de "contato". Nesse fazer ser reside, aqui, o próprio sentido - um sentido cuja particularidade, como já foi dito, é justamente a de ser, somática e sensorialmente, sentido. O que significa admitir, em outros termos, que a própria "relação intersomática se sobrepõe à intersubjetiva e que, no limite, a primeira substitui a última" (Landowski, 1996a, p.39).

Se observarmos o comportamento dos torcedores num estádio de futebol poderemos descrever experiência semelhante. De repente, não se sabe ao certo nem onde, nem quem, nem quando exatamente, começa a movimentação dos milhares de torcedores nas arquibancadas como se fossem um corpo só: gritando em uníssono em intervalos ritmados, gesticulando juntos, sentando e levantando ao mesmo tempo, fazendo as mesmas coreografias com uma harmonia de bailarinos ensaiados. Não importa se o sujeito não faz parte da torcida organizada de um dos times em campo, não importa nem mesmo se não conhece bem os hinos ou códigos de comportamento próprios àquele ritual, sem sequer se dar conta, num instante, ele pode ser co-movido ${ }^{13}$ : "contaminado" pelo sentimento do outro, tomado pela mesma emoção, levado pelo mesmo comportamento, envolvido na mesma celebração dotada de um fim em si mesma. Nesses momentos, nos quais se configura, de fato, a natureza espetacular de uma partida de futebol, o torcedor parece se esquecer de assistir ao próprio jogo para sentir, por alguns instantes, ape-

13. Termo já usado por Eric Landowski.

Significação $17 \cdot 25$ 
nas o sentir do outro. Todo o sentido produzido, nesses momentos, está em ser torcedor - uma condição que depende, aqui, da condição do outro - mais que no próprio objeto da torcida (o time) ou no objetivo do ato mesmo de torcer (estimular os jogadores).

\section{Entre o fazer e o ser}

A transmissão direta pela televisão de um jogo da seleção brasileira numa Copa de Futebol produz também, através de outro tipo de interação, o mesmo sentimento coletivo de ser torcedor. Por se tratar, no entanto, de uma experiência mediada pela $\mathrm{TV}$, este estado (ser) instaura-se, necessariamente, como o desdobramento imediato de um fazer persuasivo operado pelo conteúdo da transmissão. Neste caso, o "contato" que se estabelece entre os sujeitos depende, como já vimos, de uma duração compartilhada instaurada pela própria transmissão: todos assistindo ao mesmo tempo ao mesmo jogo que está sendo realizado justamente naquele momento em que está sendo exibido pela televisão. É nessa temporalidade comum ao enunciado e enunciação que a TV constrói, na e pela transmissão direta do jogo da seleção brasileira, o "lugar" de interação no qual todos se reúnem como uma totalidade integral comparável àquela que se forma nos estádios (ou nos teatros). É o mesmo tipo de relação espetacular que, agora em torno de uma transmissão, se articula. É também a experiência de um certo tipo de "contágio" que se desenvolve entre os sujeitos: sujeitos que são construídos pela própria TV no momento mesmo em que ela os figurativiza como parte de um só "corpo" que vibra diante da transmissão.

Se há, na transmissão direta dos jogos da Copa, um tipo de interação que pode ser descrita também como uma forma de "contágio" porque depende, sobretudo, de um tipo de contato direto entre os sujeitos, o que a distingue, porém, de uma experiência como a dos torcedores no estádio, do "riso sem razão", ditado pela intersomaticidade, ou mesmo a da dança, onde o sentido emerge, antes de mais nada, do ajustamento sensível dos dois dançarinos no ato mesmo em que se encontram e dançam? A situação vivida pelos espectadores de uma partida de futebol na TV parece ensejar a des-

Significação $17 \cdot 26$ 
crição de um dos eventuais estados intermediários - admitidos por Landowski - entre os modelos da junção e da união. Se o primeiro modelo se configura ainda em torno de um fazer fazer e o segundo, de um fazer ser, parece possível pensar, ainda em termos de categorias modais, em um regime de sentido estruturado em torno de um fazer fazer-ser. Mas por que simplesmente a descrição de um fazer fazer entre actantes não explica, na transmissão direta dos jogos da Copa, a produção de sentido neste tipo de situação? A resposta a esta pergunta começa pela compreensão do fazer que se opera nas transmissões televisivas. Como em qualquer outra situação comunicativa, a estrutura modal do fazer fazer, na TV, corresponde, de modo geral, a um "querer que o outro aja" a partir dos discursos veiculados. A primeira ação proposta por tais discursos é, neste caso, assistir à própria transmissão, já que todo programa de TV pressupõe, implicitamente, um pacto comunicativo entre o broadcaster e a audiência (cf. Casetti, 1988).

Como todo pacto, este também consiste numa relação entre os sujeitos fundada numa proposta e na sua aceitação construídas por um processo de manipulação (estratégias de persuasão que variam de acordo com a natureza da transmissão). A proposta inerente a um programa de televisão corresponde, de modo geral, ao próprio convite para assisti-lo ou, se preferirmos, à convocação para que o espectador "faça parte" da transmissão, especialmente quando o que está sendo transmitido se dá no momento mesmo em que se dá a sua veiculação e recepção pela TV. A aceitação corresponde, por sua vez, a um dever fazer ou a querer fazer parte de tal transmissão que se traduz, concretamente, pela audiência ao programa. Estabelecido este acordo inicial, a relação estabelecida entre os sujeitos (figurativizados pelo broadcaster e pela audiência) desdobra-se necessariamente em novas ações pressupostas no próprio ato comunicativo mediado pela televisão: se há discursos em circulação, há também uma intenção do enunciador de operar, através deles, um fazer saber, um fazer crer ou um fazer querer, aos quais se espera que correspondam, da parte do enunciatário, um querer saber, um querer crer, um querer querer. Toda a estrutura do pacto comunicativo instaurado por uma transmissão televisiva resume-se, enfim, a um 
fazer fazer entre sujeitos que se opera nos e por objetos particulares, os discursos ou textos portadores dos seus valores.

Voltemos agora à situação específica da transmissão dos jogos da seleção brasileira na Copa 2002, focando nossa atenção para a partida final contra a Alemanha. A construção do pacto comunicativo transcendeu os limites da própria transmissão. Perpassou, como já foi dito, toda a programação da TV no período através de flashes ou de entradas "ao vivo" do Japão nos programas que antecediam à transmissão. Como os horários dos jogos durante a Copa 2002 eram inconvenientes, o primeiro desafio enfrentado pelo broadcaster foi o de fazer a audiência aceitar a sua convocação (firmar o pacto). Não foi diferente na final de 30 de junho, quando a transmissão da final Brasil x Alemanha começou às sete da manhã de um domingo. No momento mesmo da transmissão, todo o discurso construído pelo enunciador coletivo incumbido de narrar/comentar o jogo estruturou-se, antes de mais nada, em torno de um fazer saber (o que se passava e o que se passaria na partida e no estádio) e de um fazer crer (que a seleção brasileira, ao final, venceria e conquistaria o pentacampeonato). No entanto, todos estes fazeres pareciam antes operar na construção de um outro fazer, articulado aquém e além daquela transmissão particular, assim como já ocorrera em jogos até menos decisivos: um saber e um crer para, em última instância, nos fazer ser. O que exatamente? Ser um torcedor brasileiro ou, o que parece mais exato, ser um torcedor e, por ser um torcedor, ser brasileiro (sentir-se brasileiro) com e como milhares de outros alçados a mesma condição justamente pela transmissão.

Foi a transmissão direta da final da Copa pela TV o que nos fez - naquele momento, e não em outro - rezar, vibrar, chorar juntos enquanto assistíamos à seleção brasileira jogar. Foi a transmissão direta do jogo pela TV o que, ao mesmo tempo, em diferentes lugares do Brasil, nos colocou em frente à TV como se já houvesse nisso um fim em si mesmo, como se estar diante da TV naquele momento já fosse ser, plenamente, brasileiro. Foi a TV que, enfim e em uma palavra, nos co-moveu. Mesmo quem não costumava acordar tão cedo no domingo, mesmo quem não tinha o hábito de acordar para assistir à televisão, mesmo até quem não gostava de futebol, 
não pôde ficar indiferente ${ }^{14}$ à transmissão que instaurou um daqueles "dias feriados" na programação da TV subvertendo toda a sua grade. Com a vitória da seleção brasileira, a Rede Globo dedicou o restante do dia à repercussão da conquista da seleção, tema dos programas especiais e dos habituais que foram mantidos naquele domingo. A própria televisão nos mostrou como a maioria dos brasileiros acompanhou e comemorou a conquista do pentacampeonato de futebol em torno do aparelho de TV. A transmissão direta e ininterrupta dos preparativos, do jogo e das comemorações fez sentido, naquele domingo, também por um tipo de "contágio": instaurou um daqueles momentos nos quais o próprio encontro aqui-agora entre os actantes, num espaço-tempo forjado pela própria transmissão, produz aquele tipo de relação dotada de sentido em si mesma.

Foi a televisão mesma quem assumiu, ao estender a "festa" do título ao longo de toda a sua programação domingo, que aquele regime de interação dependia da duração da sua própria transmissão. Por isso, mesmo depois do encerramento da partida, da premiação e de toda movimentação no estádio da final em Yokohama, a Rede Globo continuou transmitindo "ao vivo" dos links e dos seus estúdios no Brasil e no Japão, repercutindo a conquista do título, mas, sobretudo, fazendo da TV o "lugar" de comemoração, prolongando a vibração, instaurando um "dia festivo" pela simples interrupção de sua programação ordinária. Nesse domingo, o próprio ato de assistir à TV já se revestiu, entre nós, de um caráter extraordinário não apenas pela excepcionalidade do evento transmitido, mas, sobretudo, porque, com a interrupção do fluxo televisual, pudemos vivenciar uma espécie de "fratura" no cotidiano (cf. Greimas, 1987), uma "quebra da normalidade", para a qual a própria transmissão concorreu. E o que a Rede Globo tanto mostrou ao longo do que ela mesma batizou de "domingo da vitória"? Basicamente, o que o seu "Bate bola" programa esportivo "ao vivo" dedicado exclusivamente à Copa - já havia nos mostrado antes: jogadores, técnicos e comentaristas fa-

14. É bem verdade que nem todos aceitaram o pacto comunicativo proposto pela TV, mas, mesmo nesse caso, foi impossivel desconhecer o acontecimento midiático proporcionado pela Copa, pois, em todo o Brasil, a transmissāo foi acompanhada por manifestações de rua, fogos e buzinaços. 
zendo balanços da partida e da campanha da seleção brasileira na Copa; familiares dos jogadores da seleção e grupos de torcedores festejando o pentacampeonato nas ruas das principais capitais. $O$ tipo e o teor das inserções sobre a conquista do pentacampeonato nos programas habituais mantidos naquele domingo também se repetiam à exaustão. Não havia nada muito novo para dizer ou mostrar, nem parecia mesmo ser esta a preocupação na cobertura das emissoras de TV. Nesses momentos, quem se mantém à frente da TV o faz menos pelo que deseja saber, e mais pelo que almeja sentir: sentir juntos, sentir o sentir do outro, mas, principalmente, se sentir junto ao outro no momento em que todos sentem o mesmo. Nessas condições, emerge um novo sentido: uma estesia coletiva que se manifesta, em outros termos, como uma espécie de "contágio por adesão".

\section{O contágio por adesão}

O que representa, do ponto de vista da produção de sentido, este "contágio por adesão"? Trata-se justamente daquele tipo de interação fundada num fazer fazer-ser. Este tipo de configuração obedece, de qualquer modo, à lógica do fazer fazer (ainda que este fazer seja um fazer que se desdobra em um ser). Pressupõe ainda, portanto, uma relação transitiva entre um enunciador e um enunciatário, um intercâmbio de valores propostos por estratégias de manipulação. Mas, agora, o fazer (perceber, saber, crer) implicado neste tipo de operação, não tem outro propósito que não o de, ao final, nos fazer ser: no caso, ser torcedor e, por extensão, ser brasileiro. O sentido que emerge dos fazeres operados pelo discurso audiovisual veiculado pela televisão (àquilo a que assistimos) está justamente no regime de interação que a transmissão instaura: uma comunidade comunicativa, uma totalidade integral ("um só coração") que, forjada pela própria TV, se configura enquanto tal justamente pela adesão de cada espectador, em ato, a um mesmo "espírito de "corpo". Tudo se passa como se a própria transmissão, por nos mostrar os outros sentindo, nos fizesse sentir esse sentir do outro, quase como se estivéssemos, fisicamente, juntos, quase que "por contágio", embora não mais um "contágio" da ordem do contato intersomático, mas também da ordem do estésico. 
Parece possível falar, nesse caso, de um contágio da ordem do contato afetivo: um "contágio por adesão" que se produz quando o valor no e do discurso está na sua capacidade de fazer de si mesmo a própria instância na qual os sujeitos interagem e, no curso desta interação, deixam de se sentir um para se sentir parte do todo. $\mathrm{O}$ sentido que se produz, nesse tipo de experiência, está, sobretudo, nesse ser juntos operado antes pelo fazer persuasivo do discurso. É isso o que ocorre em transmissões, como a da final da Copa do Mundo, que, convocando cada espectador a participar de uma espécie de "corrente" proposta pela própria TV, operam justamente um fazer fazer-ser - fazer ser torcedor, fazer ser brasileiro, nesse caso específico. Não estou negando, com isso, a dimensão informativa - e a intenção comunicativa propriamente dita — deste tipo de transmissão, até porque quem liga a TV para assistir a uma final de Copa do Mundo o faz, certamente, para saber o que vai acontecer. Mas, não se pode negar também que, no modo como se articula a transmissão, a dimensão estésica se sobrepõe à informativa e, em muito momentos, oblitera esta última. Não é outra a razão pela qual a transmissão direta da partida final da Copa do Mundo, na Rede Globo, começou pelo menos uma hora antes do início do jogo, quando não havia no estádio o que se mostrar. O que a televisão pôde exibir, nesse intervalo, foi tão somente o comportamento, o sentimento, as manifestações intrínsecas ao ser torcedor, um estado para o qual ela concorreu como principal artífice.

$\mathrm{Na}$ tentativa de construir este ser-juntos, nos momentos que antecederam o início do jogo, assim como nos trinta minutos de intervalo da partida, a televisão insistiu em entradas "ao vivo" das diferentes capitais brasileiras, mostrando a concentração de milhares de brasileiros para assistir ao jogo em telões instalados nas ruas, nos bares e restaurantes, nos clubes. Quando introduzia tais inserções o próprio narrador da Rede Globo, Galvão Bueno, explicitava o objetivo da transmissão naqueles momentos: "vamos começar a passear pelo Brasil, a sentir a febre, a sentir como está o espírito do brasileiro esperando Brasil e Alemanha" (grifos meus). A tentativa de fazer da transmissão esse "lugar" no qual se dava um tipo de co-presença era tão clara que, cientes do seu papel nas entradas " ao vivo", os torce- 
dores não apenas cantavam e dançavam, gritavam e gesticulavam, mas também exibiam para às câmeras, durante os flashes, cartazes com recados para Galvão Bueno ou para outros torcedores espalhados pelo Brasil (foi o que ocorreu freqüentemente nos flashes que mostravam, por exemplo, os brasileiros no Japão dentro e fora do estádio). A consciência de que a transmissão se transformara também no próprio espetáculo - um grande evento midiático - levou esses torcedores, reunidos em torno de links da Rede Globo, a ensaiar coreografias e até a compor músicas especialmente para aquele "dia festivo" da TV: "Eu tô feliz/ meu coração não agüenta/ Eu tô feliz/ Eu tô na Globo/ Hoje é dia de penta"15 . Confessando-se emocionado, "arrepiado", foi o próprio Galvão Bueno quem melhor sintetizou, depois de um desses "giros" pelo Brasil, o sentido que a transmissão se esforçava para construir:

[...] É o Brasil inteiro se agitando, se mobilizando, é a festa do povo brasileiro! Imagine, se daqui a 90 minutos de futebol vier o pentacampeonato, o que vai acontecer por esse Brasil... A festa, essa coisa especial, esse amor tão sem explicação, tão fora dos limites, tão único, do povo brasileiro pela seleção brasileira de futebol... Aqui, no Japão, tão longe, 12 horas de fuso horário, os jogadores estão em campo e o coração do brasileiro vai bater num só ritmo, o ritmo da bola brasileira, do toque brasileiros, do passe, da ginga, da finta, do grito de gol [...] (Rede Globo, 30 de junho de 2002; grifos meus)

Momentos como estes, insistentemente levados ao ar, evidenciam o quanto a final Brasil x Alemanha pode ser apontada como exemplo privilegiado do fazer fazer-ser proposto ao espectador por este tipo de transmissão direta. Ao brasileiro que assiste a transmissão de uma partida de futebol da seleção brasileira numa disputa internacional, como a Copa do Mundo, já não é mais reservado ape-

15. Refrão do samba composto por torcedores que se reuniram na quadra da Escola de Samba Vai-Vai, em São Paulo, de onde o repórter Márcio Canuto fez suas entradas "ao vivo" no decorrer da transmissão. 
nas o papel de um mero receptor: a ele é reservado, incondicionalmente, pela transmissão da TV, um papel de testemunha ${ }^{16}$. O que distingue, numa descrição semiótica, estas duas posições? O termo "receptor" designa aqui um sujeito que, pressuposto pelo texto nos moldes de um leitor-modelo ou implícito ${ }^{17}$, tão somente interpreta o que lhe transmite um emissor, em uma função de natureza estritamente comunicativa. Já o termo "testemunha" define, ao contrário, um sujeito que, construído pelo texto televisual a partir de uma certa posição social pressuposta, exerce antes esse seu papel interpretativo "na condição de". Em outras palavras, o sujeito que testemunha é, antes de mais nada, um sujeito social: um sujeito que é (socialmente) antes mesmo de um fazer (interpretativo) ou, ainda, um sujeito que define a natureza do seu ser justamente pela operação deste seu fazer. Nos grandes "acontecimentos midiáticos", como a final Brasil x Alemanha, este sujeito corresponde justamente à função de um espectadortestemunha que, como parte da platéia imaginária reunida pela transmissão, compõe também o espetáculo em que ela própria se transforma. Numa espécie de simbiose com aquilo mesmo a que assiste, esse sujeito-testemunha (que "assiste à" na "condição de") se sobrepõe a esse sujeito-receptor (que apenas "assiste à"), conferindo, justamente por sua prevalência, historicidade a este tipo de transmissão.

O mesmo já não se pode dizer, por exemplo, em relação à maioria dos textos televisuais ficcionais (novelas, filmes, seriados, etc.). Nestes, o sujeito pressuposto pelo enunciado não parece muito diferente daquele construído pelos discursos cinematográficos. $\mathrm{Ob}-$ serva-se agora, tanto em uns quanto em outros, a nítida predominância de uma posição meramente comunicativa: o sujeito-receptor é uma instância pressuposta, mas alheia à situação que a própria transmissão instaura - uma espécie de sujeito "sem alma”, um rosto sem traços, em termos mais metafóricos. Se pretendermos identificar, nesses ca-

16. Idéia baseada na distinção que E. Goffman (1979) faz entre "posição comunicativa" e "posição social".

17. O leitor-modelo refere-se especificamente às operações interpretativas, ao "conjunto de condições de êxito, textualmente estabelecidas, que devem ser satisfeitas para que um texto seja plenamente atualizado no seu conteúdo potencial". Para uma discussão mais detalhada (cf. Eco, 1986, pp.44-46). 
sos, uma distinção entre tais sujeitos-receptores, esta já não pode se dar numa dimensão semiótica, isto é, não é "construída", não está "inscrita" no nível textual. Tal distinção só pode ser feita num plano empírico, a partir da identificação do chamado "público-alvo" de cada produto ficcional. É perfeitamente possível, por exemplo, assistirmos tanto na TV quanto no cinema a um filme sobre o "submundo" do futebol (como o filme Boleiros, de Ugo Georgetti) sem que, em nenhum dos casos, observe-se, a nível textual, a "construção" ou a "convocação" de um espectador-torcedor. $\mathrm{O}$ quadro de participação instaurado por transmissão direta de uma partida de futebol, ao contrário, não se completa sem essa "convocação" de um espectador-torcedor, cuja condição é, em parte, um produto do próprio discurso-enunciado. Este tipo de transmissão exige um sujeitor que, antes mesmo de ser um espectador, é também, e principalmente, um torcedor (ou um eleitor, numa transmissão política; ou um crente, numa transmissão religiosa, etc.): um sujeito de estado, coletivo e estésico, forjado pela comunhão - um tipo de "sentimento de pertença" — instaurada pelo sentido de "contato" que a própria transmissão produz.

Como a transmissão direta da final entre Brasil e Alemanha, pela Rede Globo, construiu este sujeito que, para ser torcedor, precisava também ser espectador? Figurativizando-o, basicamente. Para isso, não bastava mostrar as centenas de pessoas que se reuniram nas ruas para torcer, era preciso mostrar que elas se reuniam para torcer em torno de uma televisão (ou telão). Em frente à TV, o que o sujeito frequientemente via, ao longo da transmissão, era outros que, como ele (ou como se fosse ele próprio), acompanhavam o jogo também em frente à tela ${ }^{18}$."Eu me vejo vendo": era esta, em última instância, a configuração proposta em tais momentos — uma configuração capaz de, por projeção de um sujeito no outro, produzir um certo "efeito de espelho". Ora, se o sujeito vê. a si mesmo naquilo que vê, parece possível postular, até por um princípio lógico, que ele também é parte do objeto que se mostra. O que é, exatamente, este objeto? Este objeto corresponde aqui à própria situação de transmis-

18. Estas figurativizações ocorriam, de modo mais explícito, nas entradas "ao vivo" dos links espalhados pela Rede Globo nas principais capitais, mostrando as concentrações de rua dos torcedores. Nos comentários de Galvão Bueno, locutor da partida e 
são de um determinado acontecimento midiático que, por definição, só existe como uma construção também da TV. Considerando então que o próprio ato de assistir à televisão naquele momento é parte dessa situação que configura o acontecimento - midiático - parece ser justamente quando, simbolicamente, o espectador se vê vendo à transmissão que se dá também aqui um tipo de experiência fusional entre sujeito e objeto e, por extensão, entre os próprios sujeitos. É graças a tais momentos que cada um deles se sente integrado àquele todo, parte daquele "corpo", com "acesso imediato" ao outro: sujeitos em presença uns dos outros, torcendo e vibrando juntos ou, simplesmente, sendo juntos brasileiros.

Qual a natureza, enfim, desse sentido que se dá, antes de mais nada, por uma experiência afetiva em comum, ainda que esta seja mediada? Não me parece que estamos, aqui, distantes da descrição de sentido que se instaura por um sentimento de "corrente" ou de adesão, pela incorporação a uma mobilização coletiva ou a uma sensação generalizada de conectividade, ou ainda, em uma palavra, por "contágio". Não mais, no entanto, um "contágio" que se dá por qualquer tipo de "condutividade" entre corpos (soma ou phisys), passando diretamente de um ao outro, como ocorre, por exemplo, com a transmissão da eletricidade ou do calor: um "contágio" que se dá quase que por "impressão", como marca ou sinal deixado pelo contato físico, pela pressão de um corpo sobre outro. Nas experiências proporcionadas por esses momentos de "celebração ritual" da televisão, o que se tem é, ao contrário, um tipo de "contágio" que se dá por "propagação"; como se fosse possível, de modo metafórico, compará-lo à difusão por ondas elétricas ou magnéticas; um "contágio" dotado de uma espécie de natureza etérea; que se estabelece por "atração", e não mais por "impressão". Trata-se agora, enfim, de um "contágio" que se dá por adesão; um "contágio" que já não se confunde a com descrição semiótica de uma paixão porque não pode mais ser pensada apenas em termos da sintaxe narrativa da junção; porque agora, o que faz sentido é, essencialmente, estar em contato e, por meio dele, ser junto.

âncora do "Bate Bola", não faltavam, no entanto, referências verbais à própria participação e mobilização dos telespectadores pela cobertura da TV. 


\section{Bibliografia}

BARTHES, R. 1996. El teatro griego. In: Lo obvio y lo obtuso. Imágenes, gestos, voces. Trad. esp. C. F. Medrano. Barcelona: Paidós.

CASETTI, F. 1988. "El pacto comunicativo en la Neotelevisión". Documentos de trabajo. Centro de Semiótica y Teoría del Espetáculo, Fundación Instituto Shakespeare/Instituto de Cine y TV, Valencia, n.5.

DAYAN, D. \& KATZ, E. 1996. Media events. The live broadcasting of history, 3.ed., Cambridge, Massachusetts/ London, England: Harvard University. Cf. também: A história em directo. Os acontecimentos mediáticos na televisão, trad. port. Ângela e José Carlos Bernardes. Coimbra: Minerva.

ECO, U. 1986. Lector in fabula. Trad. A. Cancian. São Paulo: Perspectiva.

FECHINE, Y. 2001. Televisão e presença: uma abordagem semiótica da transmissão direta em gêneros informativos. Tese de doutorado, Programa de Estudos Pós-graduados em Comunicação e Semiótica - PUC-SP.

GOFFMAN, E. 1979. "Footing". Semiotica. Berlin/New York/Paris: Mouton Publishers, vol. 25-1/2.

GREIMAS, A. J., 1987. De l'Imperfection. Périguex: Fanlac. Cf. também: Da Imperfeição, trad. Ana Claudia de Oliveira. São Paulo: Hacker Editores, 2002.

GREIMAS, A. J.; LANDOWSKI, E. 1981. Análise semiótica de um discurso jurídico: a lei comercial sobre as sociedades e os grupos de sociedade. In: Semiótica e ciências sociais, trad. port. A. Lorencine e S. Nitirini. São Paulo: Cultrix.

LANDOWSKI, E. 2002. Presenças do outro, trad. port. M. L. Pereira et al.. São Paulo: Perspectiva.

. 2001. "En deçà ou au-delà des stratégies: la presénce contagieuse". Caderno de Discussão do Centro de pesquisas Sociossemióticas, São Paulo, n.7.

. 2000. "Estatuto e práticas do texto jurídico". Significação Revista Brasileira de Semiótica, trad. port. J. P. Mazargão. São Paulo: Annablume, n.14. 
1999a. Sobre el contagio. In: DORRA R.; LANDOWSKI, E.; OLIVEIRA, A. C. Oliveira (eds.). Semiótica, estesis, estética. São Paulo/México: EDUC/UAP.

. 1999b. "Modes de présence du visible". Caderno de Discussão do Centro de Pesquisas Sociossemióticas, n.5.

1996a. Viagem às nascentes do sentido. In: SILVA, I. A. (org.). Corpo e sentido. São Paulo: Editora da UNESP.

1996b. "Para uma abordagem sociossemiótica da literatura", Significação - Revista Brasileira de Semiótica. São Paulo: Annablume, n.11.

. 1992. Algumas condições semióticas da interação. In : LANDOWSKI, E. A sociedade refletida, trad. port. E. Brandão. São Paulo: Educ/Pontes.

REQUENA, J. G. 1995. El discurso televisivo: espéctaculo de la postmodernidad. Madri: Catedra. 